\title{
A Union of Communities
}

If there is one truth regarding ecological restoration, it is that there will always be disagreement about what defines the practice. Some practitioners insist that it involves working to restore historic ecosystems, while other people could care less about historic ecosystems and define ecological restoration broadly as a conservation technique for the renewal and/or creation of any system that promotes biological and cultural diversity. Some are only interested in restoring ecological processes, while others work to restore composition and structural features as well as processes. Some view it as restoration of space, others as restoration of place. There is an American viewpoint, a European viewpoint, a developed world viewpoint, a developing world viewpoint, an agency viewpoint, a $\mathrm{NGO}$ viewpoint, and on it goes.

Sitting here in Madison, watching all this discussion and having been immersed in it for the last 20 years, I am continually trying to make sense of the increasing cacophony of voices and definitions.

The other night, while reading a paper by Jacob K. Olupona, a professor of religious studies at Harvard, I came across a couple of concepts that I think have some merit in terms of putting this dissonance into perspective. The first is syncretism, which is defined as "the attempt or tendency to combine or reconcile differing beliefs, as in philosophy or religion" or "the fusion into one of two more originally different forms or ideas." First used in the English language in 1618, syncretism is derived from the Greek word, synkretismos, meaning "a union of communities." More recently, the Santeria priest, Oba Ernesto Pichardo described syncretism as "the tendency to identify those elements in the new culture with similar elements in the old one, enabling the person experiencing the contact to move from one to the other and back again, with psychological ease" (CLBA Journal 1999).

It may be easy to see where I'm going with syncretism, or eco-syncretism, if you will. I think eco-syncretism suggests that, as the idea of ecological restoration is promoted and dispersed more widely on a global basis, it will take on new meanings with each new culture that embraces it. As a result, the existing definitions of the current practice become intermingled with other existing practices, creating an eco-syncretic community of practitioners-that is, a community in which every practitioner believes and strives to work toward a common goal they describe and understand as ecological restoration, but with practices that fit their situation and purpose, and which may differ from other practitioners.

The other idea that I gleaned from the Olupona paper is that of centers and peripheries. In this concept of places/spaces and power, centers represent places of origin, authenticity, and authority while peripheries are seen as their binary oppositelacking in authenticity and authority, submissive to the center, and needing to return to the center (pilgrimage) to legitimize their existence.

Marcus Hall, in his recent book, Earth Repair: A Transatlantic History of Environmental Restoration (University Press of Virginia 2005), makes one of the first detailed, broad-scale attempts to portray early centers of what I like to call pre-Earth Day ecological restoration as he describes restorative work in the nineteenth-century Italian Alps, and in early twentieth-century Chicago, upstate New York, Utah, and, here, in Madison. Although Hall doesn't go this far with his analysis, I think these early centers (and very likely a few more that he doesn't describe) have served as regional dispersal points for ideas and practices that we now call ecological restoration —or, at least, they kept those ideas and practices alive until people were ready to accept them as ecological restoration. And, by doing so, these centers became the "experts," the "authorities," the places to obtain seed from, the places to visit and be inspired. Of course, as the practice of ecological restoration expands, new centers arise from the periphery, creating peripheries of their own. What I now see is the old centers, like Madison and Chicago, sharing the "stage" with new centers of restoration practice in Flagstaff, Arizona; Victoria, British Columbia; Dimoria College in northeast India; the Indigenous Peoples Network; and at various locales in Europe.

I think it would help us all, as ecological restoration expands and matures, to take a wider look and to see that, yes, there are competing views of what defines the practice of ecological restoration. But rather than view our differences as a negative, I think it behooves us to see them as a strength-not as a multifaced mask designed to frighten us but rather as a multi-dimensional, multi-named, many armed goddess to guide us. I believe that it is in our best interest to recognize, and even praise, the different approaches to ecological restoration, and in doing so identify ourselves as a "union of communities."

Dave Egan 